Moultrie, J., Nilsson, M., Dissel, M., Haner, U.-E., Janssen, S., Van der Lugt, R., Innovation Spaces: Towards a Framework for Understanding the Role of the Physical Environment in Innovation (2007) Creativity and Innovation Management, 16 (1), pp. 53-65. DOI: 10.1111/j.1467-8691.2007.00419.x

\title{
Innovation spaces: towards a framework for understanding the role of the physical environment in innovation
}

\author{
James Moultrie ${ }^{1}$, Mikael Nilsson ${ }^{4}$, Marcel Dissel ${ }^{1}$, Udo-Ernst Haner ${ }^{2}$, \\ Sebastiaan Janssen ${ }^{3}$, Remko Van der Lugt ${ }^{3}$ \\ Submitted to Creativity and Innovation Management, June 2006 \\ 1: Institute for Manufacturing, University of Cambridge \\ 2: Fraunhofer-Institut für Arbeitswirtschaft und Organisation IAO \\ 3: ID Studiolab, Industrial Design Engineering, TUDelft, \\ 4: The Knowledge Foundation ${ }^{\#}$
}

\begin{abstract}
Firms are increasingly paying attention to the physical environments in which creative and innovative activities take place. These environments reflect the firm's strategic intentions towards innovation and provide a physical embodiment of their desired modes of working. To date, this new phenomenon has received little academic attention. Based on both literature and also the authors' combined experiences through observing firms in Europe, this paper proposes a simple framework to aid practitioners and academics to better understand the design, role and goals of such spaces.
\end{abstract}

\section{INTRODUCTION}

There is significant evidence of the importance of innovation to a firm's ongoing commercial success. The need to maintain current market position and gain new markets places innovation as a fundamental strategic issue in most companies [Christensen 1997]. Innovation demands intertwined processes of ideation, creation, design and delivery, supported by an appropriate managerial infrastructure to balance risks against rewards. New challenges in implementing these processes rapidly, often across organisational boundaries have resulted from continual developments in global economies, technology, and information and communication systems.

This paper takes the perspective that the spaces in which creative and innovative activities take place are an important part of the innovation process in an organisation. Designing effective workspaces to create desirable spatial interactions is becoming the focus of organisational efforts in many firms. It is also apparent that companies are paying close attention to the design of the physical environments in which innovative activities takes place. For example, design consultancy IDEO make strong claims about the way in which their environment and

\footnotetext{
\# Work on this paper started at the Interactive Institute, Sense Studio. Financial support from EU Objective 1 Södra Skogslän region and studio partners is gratefully acknowledged.
} 
infrastructure enhances their creativity and innovation performance [Kelley \& Littman 2001]; their whole workspace not only reinforces their corporate values, but supports innovative activity through the provision of appropriate resources, visualisation and model making facilities and the ability to reconfigure for new projects. Some of the larger consumer goods companies have created spaces for encouraging consumer input [Bitner 1992] into new concept development (e.g. Kodak, British Telecom \& Nokia). In addition, many companies are beginning to consider how the work infrastructure supports effective group work and communication, for both distributed design teams and also the day-to-day activities of product development teams (e.g. Cisco). Other companies have developed dedicated spaces to support group creativity and encourage creativity as a key component of innovation, (e.g. Royal Mail, Dutch Tax Office). Finally, several organisations have created dedicated environments for demonstrating and evaluating new products (e.g. Philips, British Telecom). Despite the emergence of such spaces, there is little empirical evidence of their benefits or of the wider implications of the design of the workspace on innovation. Furthermore, there is little that takes this notion further to identify the characteristics of effective environments. It appears that firms are creating spaces based on instinct and personal judgement, rather than genuine insights based on firm evidence.

Research investigating the role or implications of the physical environment in supporting creativity and innovation is sparse and somewhat fragmented. Early explorations include a consideration of the spatial structuring of workplaces by Tom Allen [1966]. More recently, Bitner [1992] investigated the impact of surroundings on employees. Duffy [1997] analysed how office design supports new ways of working, with technology enabling a blurring of the boundaries between home and the office. These studies are typical of work looking more widely at how the workplace influences work performance and do not focus explicitly on innovation. The way in which office spaces are changing has been reported in several recent books, mainly illustrating developments in style, configuration and technology [e.g. Zelinsky, 2004]. Myerson \& Ross [2005] have reviewed how the design of the workplace is changing in response to organisational, social and technological change, providing detailed case(s) studies. In an earlier book, Turner \& Myerson [1998] explored the relative benefits of different classes of work environment. There is growing interest in the interaction between spatial location and interaction. This work has in part been fuelled by the reverse impact of new technology, that rather than unfettering the firm has made co-location increasingly important [Malmberg \& Maskell 2002]. More recently, there have been attempts to understand the connection between the design of workspaces and creativity in innovation. Lewis \& Moultrie [2005] focused specifically on 'innovation laboratories', whilst Wycoff \& Snead [1999] focused on the development of creativity rooms as an input to innovation. Finally, Kristensen [2004] considered the wider implications of how workspace design influences innovation. 
There is therefore a gap in current work in understanding how the environment impacts innovation performance and how this performance matches the underlying strategic intentions of the organisation. In addition, there is a need for greater clarity on the characteristics/components of such spaces and how they actually support innovation. This paper therefore aims to provide a framework, to be used as a basis for classifying and comparing the design of different innovation environments. The framework synthesises insights from literature, practitioner perspectives, and earlier exploratory cases. Specifically, the outline framework emerged as a result of ongoing interaction among a group of researchers who presented on this topic at the 'Creativity and Innovation Management' workshop in Oxford 2005 [van der Lugt et al 2005, Haner 2005, Nilsson 2005, Lewis \& Moultrie 2005]. This paper has developed from the authors' combined experiences of creative environments throughout the EU (including UK, Scandinavia, Germany, Benelux) and the US. Some of these experiences have been published earlier, including at the workshop mentioned above, or are in different stages of development. Two specific descriptions of cases and experiences that have been brought into the development of this framework are covered in two other papers in this special issue:

> van der Lugt [2007] introduces the 'Future centre' of the Dutch Tax and Custom Administration. The facility is inspired by the design of a 'shipyard, created to physically anchor the processes of creativity and innovation within the organisation.

> Haner \& Stohr [2007] discuss the integration of spatial and technical infrastructure as an enabler of creativity, collaboration and cooperation. Specific cases discussed include Daimler/Maybach and Hewlett Packard.

Where appropriate, brief examples from both of these papers have been included to help to explain or underpin the concepts.

In addition to providing an academic foundation for this phenomenon, the framework may also provide practitioners with a structured way of considering how their work environments support innovation and how they can assess the impact of potential changes. The framework outlines components and classifications that can be used to analyze the enhancement of physical spaces in the service of innovation.

Following a brief literature review addressing the topic from a number of different perspectives, the outline framework will be described. The paper will end with a discussion of implications for theory and practice, followed by some brief conclusions. 


\section{DEVELOPMENT OF A FRAMEWORK}

As an emerging phenomenon, with little previous research, this paper aims to present an outline framework, for use by both practitioners and academics in understanding how the physical environment can be considered in the wider context of creativity and innovation.

As a conceptual foundation, we use a simple transformation model, representing the progression from inputs through to outputs [e.g. Woodman et al 1993]. This model enables the consideration of both how the companies strategic intent may be translated into specific innovation environments and how these spaces are subsequently used to deliver new products and services (Figure 1).

\section{FIGURE 1 ABOUT HERE}

Using this transformation model as a template, it is possible to describe two related transformation processes. The first is the process by which an innovation environment is created in order to satisfy strategic goals. The second is the process by which the space is then used and the degree to which strategic goals are met (see figure 2).

\section{FIGURE 2 ABOUT HERE}

Thus, literature is presented in two sections. Firstly, extant literature is presented to explore the design and creation of dedicated environments to support innovation, taking a strategic perspective, to understand why a firm should consider the physical environment as a vital contributor towards strategic goals. Secondly, the usage of the innovation environment is explored, to better understand how the physical space can connect to processes of creativity, design and innovation.

\section{Strategic intent and process of creation}

Pavitt [1991] noted that the majority of past empirical research on innovation has identified key characteristics of the large innovating firm to be primarily firm specific competences that are built around knowledge and skills that are organisationally distinct. Dougherty and Hardy's work [1996] suggested that successful product innovation was usually driven by the personal experiences of lower-level managers operating within established networks and leveraging personal connections. This raises the issue of how the creative performance of individual employees may be promoted, and how this may be influenced by the culture of the workplace. Issues that have been explored include the workplace layout, hierarchy and leadership mostly from a psychological perspective [Amabile 1999; John-Steiner 2000]. Although as Van de Ven et al [1999] point out, the underlying theoretical principles of creativity in individuals have received scant attention within the innovation literature, especially from an organisational [Woodman et al 1993] and social psychological perspective [Hargadon 2002]. 
Olson et al [1998] view design as inherently strategic through its inherent user and market orientation. They define design strategy as "the effective allocation and coordination of design resources and activities to accomplish a firm's objectives of creating its appropriate public and internal identities, product offerings and its environments". However, the importance of design as a strategic resource has frequently been neglected [Kotler \& Rath 1984] and has largely been overlooked in the body of research [Olson et al 1998]. Elements of a design strategy typically focus on 'conveying an appropriate image to the world' [Olson et al 1998 p55] including all aspects of the organisations visual identity. Thus, a firm's design strategy should encompass the design of communications (including identity), products (and services) and operating environments. Olson et al [1998] also noted that "environmental design carries the potential of having a direct impact on worker morale and productivity" and should encompass architectures, interiors and landscaping of both customer facing and working areas. Such approaches are evident in the consistency of the design of Apple's retail outlets with the design of their products, services and packaging.

The external environment has played a central role in major strategic models, such as the 5 environmental forces of Porter [1979]. Understanding and reacting to competitive activity is seen as key to creating a competitive advantage. In this context, the 'environment' is typically the external world, as opposed to the internal location of company activities. As a reaction to these market/externally oriented strategies, a perspective emerged that is largely based on a Schumpeterian view, where innovation and creative responses are considered to be most important. Notably the resource based view emerged based on the work of Penrose [1959] and takes an internal perspective on strategy, describing the type of resources a firm should have to create and maintain a competitive advantage. Barney [1991] commented that a firm's resources need to be valuable, rare, imperfectly imitable and non-substitutable in order to create a sustainable competitive advantage. Innovation theorists have embraced these concepts to develop theories that aim to understand how organisation can create the necessary (combination) of resources to sustain competitive. Examples of these concepts are the framework of dynamic capabilities [Teece 1994, Teece et al 1997, Eisenhardt and Martin 2000, Zollo and Winter 2002], combinative capabilities [Kogut \& Zander 1996], absorptive capacity [Cohen \& Levinthal 1990] and complementary assets [Tripsas 1997].

In the context of the workspace, these above perspectives result in different perspectives on how the local environment might contribute to innovation:

> From a design perspective, there are implications for how the design of different working and customer facing environments fits within the firms wider design strategy. 
> From an innovation perspective, it is evident that firms can adopt a range of innovation strategies and that the workspace might contribute towards the productivity and effectiveness of both co-located and distributed teams.

> From a strategic perspective, there are implications for how the design of the environment enables the development of unique capabilities, enables reconfiguration of capabilities to changing demands, and supports synergies between complementary assets. This raises the question of whether or not the physical environment can be a strategic resource in it's own right and as such can contribute towards these routines? Innovation spaces can be understood as catalysers for an organisation's ability to rapidly reconfigure resources within a flexible workspace and infrastructure. Yet concepts such as capabilities and resources are still relatively abstract and it is thus a challenge to propose concrete measurable routines that have this effect.

Thus, literature suggests that an organisation should have a clearly articulated innovation strategy. If the physical environment can potentially support in the delivery of the innovation strategy, then it is fair to assume that there should be explicit motivations behind the design of the innovation environment. The outline framework must therefore reflect this link, connecting the actual physical characteristics of the environment with the desired strategic goals of the organisation. Finally, the framework should also reflect the importance of assessing the degree to which these goals have been met.

For example, in the Royal Mail in the UK [Lewis \& Moultrie 2005], the organisation invested in the development of an 'innovation laboratory' to kick-start innovative behaviour in the organisation, to explore the implications of new technology and to reinforce the perceived strategic value of innovation. The facility was created in stages, following an initial pilot facility and with inspiration from entertainment environments. In use, groups from across the business are typically facilitated through structured brainstorming sessions, using a combination of IT based and visually led resources. In application, the facility clearly demonstrated its effectiveness in operation, although there was little formal evaluation of the degree to which the original strategic intentions had been met.

Thus typical motivations for considering the innovation environment as a part of the overall innovation or business strategy are outlined in table 1 . In the experiences of the authors, it is evident that firms rarely have explicit strategic goals underpinning the creation of dedicated and general working environments. Instead, there is commonly a single champion who is a compelling sales person and believes passionately in the concept. The existence of an underpinning strategic intent can prevent both dedicated facilities and everyday working environments becoming vacuous spaces with a superficial purpose. 
If the spatial design of innovation environments can provide a strategic resource, then it is also desirable that the strategic intent is made explicit. This enables the firm to measure and establish the degree to which this intent has been realised. Realised intent may be measured through a range of qualitative (e.g. staff perceptions) and quantitative (e.g. number of ideas) means. In addition to the explicitly articulated motivations underlying the design of innovation inducing work environments, there may also be implicit motivations; such as a response to a fundamental change in orientation of the firm.

The underlying 'innovation intent' provides the stimulus for designing a specific innovation environment. However, this only provides a starting point for the process of design. It is also necessary to consider how this environment links to the wider innovation process. Is it intended for example that the environment addresses all innovation activities or is it targeted at a specific aspect. For example, at Philips Research, their 'HomeLab' provides a temporary residence for research staff to explore the implications of new technologies in a replica consumer context. This provides insight into the early stages of innovation as well as enabling consumer feedback on later stage concepts. It provides a laboratory for both ideation as well as evaluation, by observing real people interacting with new products. In this example, the potential users of the environment are research staff, designers and also consumers. The lab aims to support innovation by bringing technology and the market closer. Philips claims that this environment is essential in speeding up the time to market for technological innovation, by bridging the span of the whole innovation process.

The above example is of a dedicated environment within a single company. However, other facilities exist where participants from a range of organisations are brought together to address a specific issue. Thus, a key element of both creating and using an innovation environment is understanding the needs and type of people who will use the space, including the degree to which independent facilitation is required. It is also evident that in practice, any work environment/space will evolve to accommodate other uses from the original intentions, as well as come to manifest the work undertaken there. These factors are summarised in table 2.

\section{TABLE 2 ABOUT HERE}

\section{Process of use and realised intent}

In the experience of the authors, firms have considered their environments to support or enable innovation, creativity or design. These factors will now be described, and are summarised in table 3. 


\section{Usage: creativity}

Creativity is often viewed as essential to support innovation and the development of new technologies. To exploit this source of advantage, companies are increasingly seeking to enhance the creativity of their product development teams [Feurer et al. 1996, Cagan \& Vogel 2002]. Indeed, Bennis [1997] described this ability as critical to survival. Creativity as a field of enquiry takes a range of perspectives, from creativity and the individual [Kirton 1989], the creative process [Baxter 1995] and the organisational climate [Amabile 1999]. In the context of this paper, it is the 'organisational climate' that is most relevant as it plays an important role in people's willingness to express their creativity [Damanpour 1991]. Key dimensions on which climate can be evaluated were developed by Ekvall [1997] and further evaluated by Isaken et al [1999] and others. These dimensions include: challenge, freedom, dynamism/liveliness, trust/openness, idea time, playfulness/humour, conflicts, idea support, debate, and risk-taking. Similarly, Amabile [1996] derived six categories of environment: challenge, freedom, resources, work-group features, and supervisory encouragement.

However, in these studies the environment in question is the cultural and managerial context within the firm. There is little consideration of the implications of the physical space on creativity. More recently, it has been recognised that attributes of the physical 'locality' can also act as catalysts for creativity; the local resource of visual materials and stimuli, intensive social and cultural activity and the established reputation of the location as a source of inspiration [Drake 2003]. Thus, the design of the environment can physically reinforce Ekvall's [1996] dimensions of dynamism, playfulness and debate [Lewis \& Moultrie 2005]. However, despite much anecdotal evidence that the physical environment may positively influence creativity, there has been little empirical exploration of this phenomenon. Thus, to support creative activities, the physical environment must reflect and enable an organisational climate which supports creativity in addition to providing a physical reinforcement of desirable creative behaviours.

In an organisational setting, creativity can be defined as "an ongoing process of problem finding, problem solving, and solution implementation activity" [Basadur 1993]. Problem finding (as opposed to simply problem solving) is particularly important in the NPD domain [Smilansky \& Halberstadt 1986, Kirton 1989]. Problem finding includes identifying new product or service opportunities by anticipating new customer needs. However, the identification of new opportunities alone is insufficient. These opportunities must be translated into saleable artefacts and problem finding must be closely coupled with problem solving as an integrated process. For Newell et al [1962] the relationship between problem solving and creativity is that of set and subset: "Creative activity appears ... simply to be a special class of problem solving activity characterised by novelty, unconventionality, persistence and difficulty 
of problem formulation". Creativity can be seen as essentially "part of the same cognitive function as problem solving" [Kirton 2003]. Several innovation environments have been created with the explicit motivation of supporting effective creative processes, through the provision of spaces designed around different stages of the creative process. Such facilities might include spaces dedicated to exploration, with different environments to enable reflection or evaluation.

\section{Usage: product \& service design}

Baxter [1995] described creativity as "at the heart of design, at all stages throughout the design process". Weiss [2002] notes that "designers are well positioned to help companies unlock their capacity for innovation because they naturally take an inductive approach to the problem solving process, and employ powerful visualisation techniques to communicate the results".

Many prescriptive models of the design process take this problem oriented approach, with early emphasis on analytical activity to clearly establish the nature of the real problem, the constraints and the target specification. In contrast, descriptive models emphasise the generation of an early solution, which is subsequently evaluated and refined [Cross 1998]. In a study of several creative designers, Roy \& Potter [1993] noted that many inventors adapt the latter strategy, with the generation of an initial idea based on the inventor's accumulated repertoire of knowledge and experience. Dorst \& Cross [2001] however noted that the creative element of design can be described as a co-evolution of problem/solution spaces. Thus, the physical environment can potentially support both the design process, supporting problem finding, solving and design implementation through provision of suitable tools and resources. This is especially evident in design firms, such as IDEO, where the spaces support visualisation, exploration and inspiration through access to materials and artefacts. In other consultancies, the environment enables concept evaluation through focus groups and user testing in spaces which enable reliable data collection.

\section{Usage: innovation}

A firm's innovation strategy reflects the various choices that a firm must make about its competitive orientation. Gilbert [1994] suggested that companies can either reactively respond to external activities or proactively deliver radical and inventive new products which drive an external response. Other authors have identified the degree to which the firm is customer focused, technologically focused or responsive to competition [Gatignon 1997, Lynn \& Akgun 1998]. Lynn \& Akgun [1998] also noted that the choice of innovation strategy focus is contingent upon the degree of technological and market uncertainty. Writers on technological innovation suggest that a key focus of the innovation strategy is the degree to which a company delivers radical, discontinuous or breakthrough innovations to the market 
[Christensen 1997]. The design of the physical environment should thus ideally reflect and enable the delivery of the firm's innovation strategy.

The innovation process provides an organisational mechanism that aims to place these creative activities within a managerial structure [Otto \& Wood 2001]. This managerial structure aims to balance the creative needs of the design team against the needs for certainty and control of the business. Thus, the environment should also consciously connect with the firm's innovation process. However, in the authors experiences, many dedicated environments generate results which are disconnected from the wider innovation process. As a result, the performance and viability of the spaces is difficult to establish.

\section{Usage: teamwork}

It is evident from experience of several spaces, that a common implicit goal and occasional explicit intention is the desire for the physical environment to enhance teamwork. This may be for dedicated project teams through to occasional/informal groups. There is a well established body of work on proximity of team members in innovation [e.g. Allen 1966] and on the role of the environment on group effectiveness [Sundstrom \& Altman 1989]. More recently, there is work exploring the role of new technologies in enabling virtual teamwork [Malone 2004, Nunamaker et al 1988, Gallupe et al 1992].

\section{TABLE 3 ABOUT HERE}

\section{Physical embodiment of intent}

It is perhaps simplest to describe innovation environments in terms of the characteristics of the physical space. However, to do this without considering the usage, creation and intentions of the space provides little insight into the role and effectiveness of the different physical elements. For example, if the goal is to improve team communication, then physical elements such as flexible workspaces and informal social areas may be appropriate. In contrast, if the intent is to generate and capture radical ideas, then the facility may emphasise group dislocation, playfulness and provide physical or visual sources of inspiration.

The primary physical distinction between various environments is the physical context; the degree to which the facility is independent from the normal working environment, the degree of flexibility and the actual location. Next, it is evident that the actual design of different spaces may vary, with a range of design values, different degrees of flexibility and also different perspectives on design evolution.

Modelling and visualisation of ideas and concepts is a core component of innovation, design and creative processes [Kelley 2001, Baxter 1995]. The provision of resources, facilities and tools to enable these activities is often a core element of innovation environments. Thus, different spaces contain varying levels of physical resources, from the IT infrastructure for 
communication through to the provision of support for modelling and visualisation. Similarly, to enable effective decision making, spaces may enable access to relevant data, information and process specific content.

It is also possible to distinguish between the different physical characteristics of alternative innovation environments. The design of the space varies greatly, with a range of design values, different degrees of flexibility and also different perspectives on design evolution. Different spaces contain varying levels of physical resources, from the IT infrastructure through to the provision of support for modelling and visualisation.

Each of these components is realised within genuine constraints on resources, space and skills. Furthermore, it is likely that the physical space will evolve in response to changes in priorities, finances and perceived benefits. These factors are summarised in table 4 .

\section{TABLE 4 ABOUT HERE}

\section{Realised intent}

In the authors' experience, firms that have consciously created dedicated innovation environments are typically weak in establishing the contribution that these spaces make to innovation performance. In part, this is due to weaknesses in describing clear strategic or operational intentions underpinning these environments. This lack of explicit goals makes any assessment of performance difficult. Instead, judgement is often anecdotal, with positive testimonials and compelling stories. For dedicated workshop spaces, participants may complete feedback forms. However, these forms only provide instantaneous feedback on the session itself and do not enable judgement on the achievement of wider strategic goals. Recognising this weakness, it is essential that any discussion of innovation environments includes consideration of measures (quantitative and qualitative) which might indicate the degree to which these goals have been met.

\section{DISCUSSION \& FURTHER WORK}

The authors collectively have experienced many examples of creative environment, from novel offices for dedicated teams, through to innovation hot-houses and idea-generation rooms. By their very nature, these spaces are often fun, exciting and engaging. For this reason, previous work investigating innovation/creative environments often focuses on the characteristics of the space itself.

This paper has sought to frame such considerations in the wider context of the firm, to link the environment to the firm's strategic goals. By taking this perspective, it becomes possible to make judgements on the way in which the environment actually contributes to the achievement of these goals. Based on a simple transformation model, the processes of creation and use of 
innovation environments has been described. A summary of this discussion is presented below in the form of a conceptual framework (figure 3). Fundamentally, this framework recognises that the environment itself can form part of the firms innovation strategy and can influence performance in innovation. Thus, the environment should be a conscious (rather than ad-hoc) aspect of any innovation strategy. In addition, if a firm is to invest resources in the creation of a dedicated innovation environment, then it is essential that the strategic intentions underpinning this space are explicit.

\section{FIGURE 3 ABOUT HERE}

This framework has implications for both theory and practice:

> From a research perspective, the framework provides a theoretical foundation by which alternative environments might be analysed and evaluated. This is an important contribution as while there is anecdotal evidence of the value of innovative spaces, there is little rigour underpinning this work. Specifically, by linking the strategic and realised intent, the framework provides the basis of a protocol for evaluating the effectiveness of different types of environment. In addition, where previous work has focused on a narrow subset of workspaces (e.g. idea rooms), this framework aims to encompass all spaces in which creative activities might take place.

> For industrialists, the framework provides a structure by which the creation, application and evaluation of innovative spaces might be considered in a systematic manner.

In both cases, there are implications for further work. The framework can be used as the basis of wider research investigating the design of innovation environments in a range of firms in different sectors. Specifically, it would be of use to understand whether environments that have been consciously designed result in better innovation performance than those that have evolved in an ad-hoc manner. In addition, it would be useful to determine the specific characteristics of those environments that have the greatest impact on innovation performance.

It is evident from the authors' experiences that there are many derivative workspaces, copying elements of environments experienced in other firms. However, due to different strategic and operational contexts, such derivative spaces may not translate so easily from one firm to another. Such derivative spaces may potentially have a negative rather than a positive impact on innovative performance. Thus, from a practioner perspective, the framework can be further developed to provide specific guidance (supported by case examples) on the creation of innovative environments appropriate to the firm's unique context. This could also form the basis of further action-oriented research. By following such a process, it is hoped that firms may minimise the creation of inappropriate spaces due to the desire to follow the latest managerial fads. Arguably, the greatest opportunity for such spaces is as a mechanism for 
bringing functional/technical specialists together with customers and users of their products or services.

By encompassing all types of innovative environments, it is perhaps necessary to distinguish between those facilities which genuinely relate to a firm's innovation capability and those which are essentially training or conference facilities. It may also be necessary to expand the scope of the model to encompass environments that impact on innovation but are not traditionally considered as related to innovation. Such spaces might include social spaces, the boardroom and other meeting rooms.

\section{REFERENCES}

- Allen T, (1966), Managing the flow of scientific and technological information, Massachusetts Institute of Technology, Cambridge, MA

- Amabile T M, (1999), How to kill creativity, Breakthrough Thinking, 1-59, Harvard Business School Publishing, Boston

- Amabile T M, Conti R, Coon H, Lazenby J, Herron M, (1996), Assessing the work environment for creativity, Academy of Management Journal, Vol. 39, pp.1154-1184

- Barney J B, (1991), Firm resources and sustained competitive advantage, Journal of Management, Vol. 17 (March), pp99-120

- Basadur M, Robinson S, (1993), The new creative thinking skills needed for total quality management to become fact, not just philosophy, American Behavioural Scientist, Vol. 37 No. 1

- Baxter M, (1995), Product design: A practical guide to systematic methods of new product development, Chapman \& Hall, London

- Bennis W, Biederman P W, (1997), Organizing Genius: The Secrets of Creative Collaboration, Addison Wesley Longman, USA

- Bitner M J, (1992), Servicescapes: the impact of physical surroundings on customers and employees, Journal of Marketing, Vol. 56, April, pp.57-71.

- Cagan J, Vogel C M, (2002), Creating breakthrough products: innovation from product planning to program approval, Prentice Hall, Upper Saddle River, New Jersey

- Christensen C M, (1997), The Innovator's Dilemma, Harvard Business School Press, Boston

- Cohen W M, Levinthal D A, (1990), Absorptive Capacity: A new perspective on learning and innovation, Administrative Science Quarterly, Vol. 35

- Cross N, (1998), Engineering Design Methods - Strategies for Product Design, John Wiley \& Sons, England

- Damanpour F, (1991), Organisational Innovation: A meta analysis of effects of determinants and moderators, Academy of Management Journal, Vol. 34 No. 3 , September, pp.555-590

- Dorst K, Cross N, (2001), Creativity in the Design Process: co-evolution of problemsolution, Design Studies, Vol. 22, No. 5, pp. 425-437

- Dougherty D, Hardy C, (1996), Sustained product innovation in large mature organisations: overcoming innovation-to-organisation problems, Academy of Management Journal, Vol. 5, pp1120-1153 
- Drake G, (2003), This place gives me space: place and creativity in the creative industries, Geoforum, Vol. 34, pp511-524

- Duffy F (1997), The new office: with 20 international case histories, Conran Octopus, London

- Eisenhardt K M, Martin J A, (2000), Dynamic Capabilities: What are they?, Strategic Management Journal, Vol. 21, pp1105-1121

- Ekvall G, (1997), Organisational Conditions and Levels of Creativity, Creativity and Innovation Management, Vol. 6 No. 4, pp195 - 205

- Feurer R, Chaharbaghi K, Wargin J, (1996) Developing Creative Teams for Operational Excellence, International Journal of Operations and Productions Management, Vol. 16 No. $1, \mathrm{pp} .5-18$

- Gallupe R B, Dennis A R, Cooper W H, Valacich J S, Bastianutti L M, Nunamaker J F, (1992), Electronic Brainstorming and Group Size, Academy of Management Journal, Vol. 35 No. 2, pp.350-269

- Gatignon H, Xuereb J M, (1997), Strategic orientation of the firm and new product performance, Journal of Marketing Research, Vol. 34 February

- Gilbert J T, (1994), Choosing an innovation strategy: theory and practice, Business Horizons, Nov-Dec, p99

- Haner U E, (2005), Space for creativity and innovation: two cases, $1{ }^{\text {st }}$ Creativity and Innovation Management Community Workshop, March 2005, Oxford

- Haner U E, Stohr C, (2007), The 'garage' ashybrid workplace infrastructure for entrepreneurs: an explorative investigation, Creativity and Innovation Management, Vol. 16 No. 1

- Hargadon A B, (2002), Brokering knowledge: Linking learning and innovation, in Research in Organisational Behaviour, Vol. 24, pp41-85

- Isaken S G, Lauer K J, Ekvall G, (1999), Situational Outlook Questionnaire: A measure of the climate for creativity and change, Psychological Reports, No. 85

- John-Steiner V, (2000), Creative Collaboration, Oxford University Press, New York

- Kelley T, Littman J, (2001), The Art of Innovation: Lessons in creativity from IDEO America's leading design firm, Currency Doubleday, New York.

- Kirton M J, (1989), Adaptors and innovators: Styles of creativity and problem solving. London, Routledge

- Kirton M J, (2003), Adaption-Innovation In the Context of Diversity and Change, London, Routledge

- Kogut B, Zander U, (1996), What firms do? Coordination identity and learning, Organisation Science, Vol. 7 No. 5, pp502-518

- Kotler P, Rath A, (1984), Design: a powerful but neglected strategic tool, Journal of Business Strategy, Vol. 5 No. 2, p16

- Kristensen T, (2004), The physical context of creativity, Creativity and Innovation Management, Vol. 13 No.2, pp 89-96

- Lewis M, Moultrie J, (2005), The Organisational Innovation Laboratory, Creativity and Innovation Management, Vol. 14 No. 1, p.73

- Lynn G S, Akgun A E, (1998), Innovation strategies under uncertainty: a contingency approach for new product development, Engineering Management Journal, Vol. 10 No. 3 pp11-17 
- Malmberg A, Maskell P, (2002), The elusive concept of localisation economies: towards a knowledge-based theory of spatial clustering, Environment and Planning, Vol. 34, pp429449

- Malone T W, (2004), The Future of Work: how the new order of business will shape your organisation your management style and your life, Harvard Business School Press, Boston, MA.

- Myerson J, Ross P, (2005), The 21st Century office, Laurence King Publishing, UK

- Newell A, Shaw J C, Simon H A, (1962), The processes of creative thinking, in Contemporary Approaches to Creative Thinking edited by Gruber H E, Tyrell G \& Wertheimer M, New York, Atherton Press

- Nilsson M, (2005), An exploration of the connection between creativity, innovation, design of workspace and the impact of technology, $1^{\text {st }}$ Creativity and Innovation Management Community Workshop, March 2005, Oxford

- Nunamaker J F, Applegate L M, Konsynski B R, (1988), Computer-aided deliberation: Model management and group decision support, Journal of Operations Research, Vol. 36, pp.826-848

- Olson E M, Cooper R, Slater S F, (1998), "Design Strategy and Competitive Advantage," Business Horizons, 41, (March/April).

- Otto K, Wood K, (2001), Product design: techniques in reverse engineering and new product development, Prentice Hall, USA

- Pavitt K, (1991), Key Characteristics of the Large Innovating Firm, British Journal of Management, Vol. 2 No. 1, pp41-50

- Penrose E T, (1959), The Theory of the Growth of the Firm', Oxford: Oxford University Press

- Porter M, (1979), How competitive forces shape strategy, Harvard Business Review, March/April

- Roy R, Potter S, (1993), The commercial impacts of investment in design, Design Studies, Vol. 14 no. 2, April

- Smilansky J, Halberstadt N, (1986), Inventors versus problem solvers: An empirical investigation, Journal of Creative Behavior, Vol. 20, p183-201

- Sundstrom E, Altman I, (1989), Physical Environments and Work-Group Effectiveness, Research in Organisational Behaviour, Vol. 11, pp.175-209

- Teece D J, Pisano G, (1994), The dynamic capabilities of firms: An introduction, Industrial and Corporate Change, Vol. 3 No. 3, pp537-556

- Teece D J, Pisano G, Shuen A, (1997), Dynamic Capabilities and Strategic Management, Strategic Management Journal, Vol. 18 No. 7, pp.509-533

- Tripsas M, (1997), Unraveling the process of creative destruction: complementary assets and incumbent survival in the typesetter industry, Strategic Management Journal, Summer Special Vol. 18, pp119-142

- Turner G, Myerson J, (1998), New workplace new culture: office design as a catalyst for change, Gower Publishing, London

- Van de Ven A H, Polley D, Garud R, Venkatraman S, (1999), The innovation journey. New York: Oxford University Press

- van der Lught R, Janssen S, Stappers P J, (2005), Enhancing involvement: explorations with use of place and time in creative group processes, $1{ }^{\text {st }}$ Creativity and Innovation Management Community Workshop, March 2005, Oxford 
- van der Lught, (2007), Future center the shipyard: learning from practice, Creativity and Innovation Management, Vol. 16 No.1

- Weiss L, (2002), Developing tangible strategies, DMI Review, Design Management Institute, Vol. 13 No. 1

- Woodman R W, Sawyer J E, Griffin R W, (1993), Toward a theory of organisational creativity, Academy of Management Review, Vol. 18, pp293-321.

- Wycoff J, Snead L, (1999), Stimulating innovation with creativity rooms, The Journal for Quality \& Participation, March / April

- Zelinsky M, (2004), The inspired workplace: design for creativity and production, Rockport Publishers Inc, USA

- Zollo M, Winter S G, (2002), Deliberate learning and the evolution of dynamic capabilities, Organisation Science Vol. 13, pp339-351 


\section{TABLES AND FIGURES}

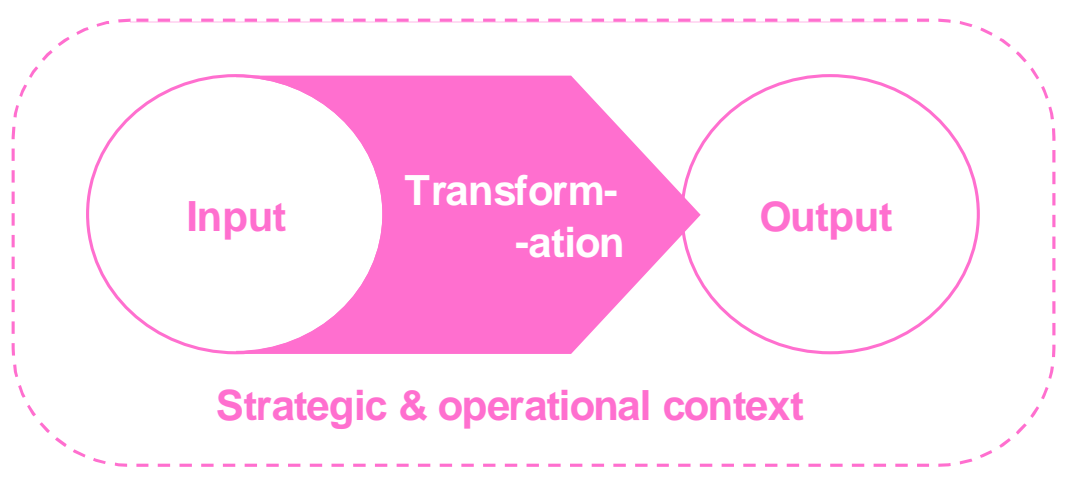

Figure 1: transformation model (based on Woodman et al 1993)

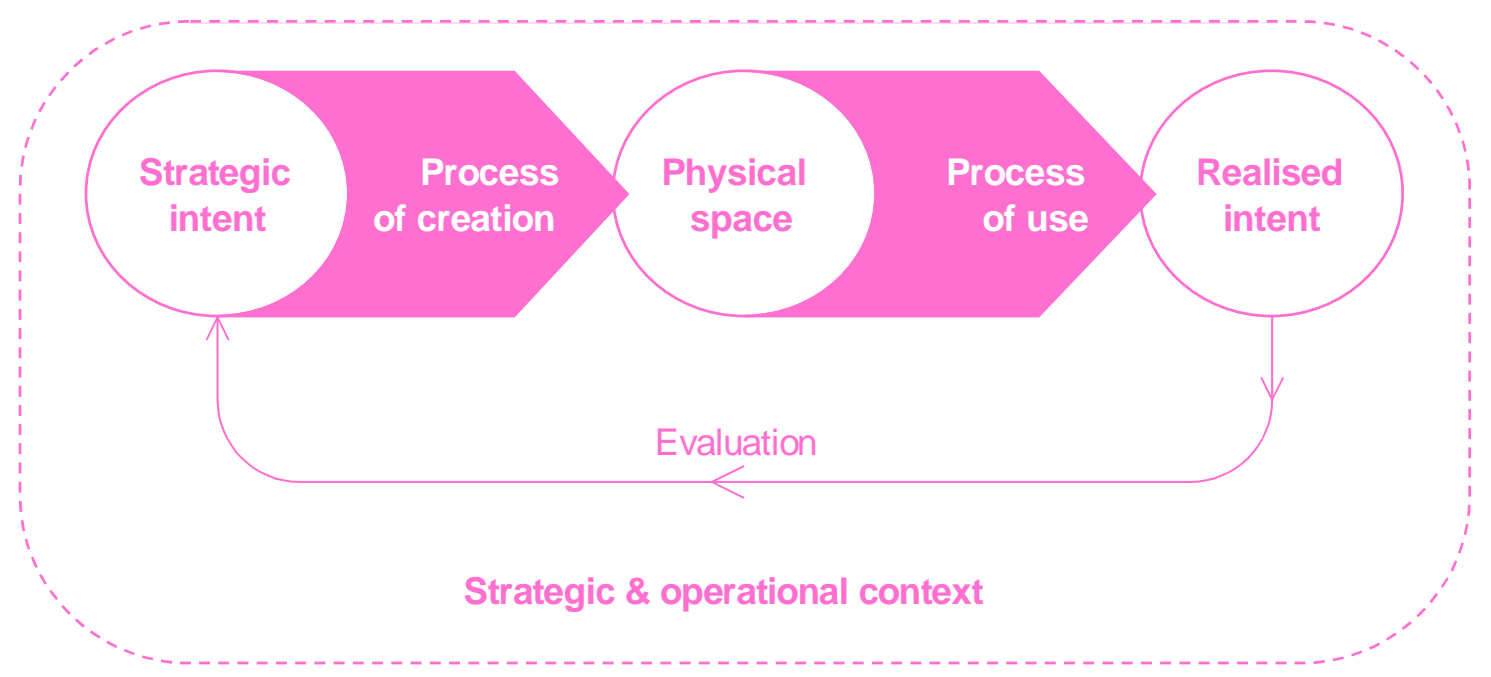

Figure 2: Outline framework - process of creation and process of use

\begin{tabular}{|c|c|}
\hline \multicolumn{2}{|r|}{ Strategic intent } \\
\hline Strategic goals & To support the firms basis of competition \\
\hline Symbolic goals & To symbolically reinforce the firm's innovation strategy or corporate values \\
\hline $\begin{array}{l}\text { Innovation } \\
\text { efficiency }\end{array}$ & To reduce innovation costs, improve staff productivity, improve speed or lower facility costs \\
\hline $\begin{array}{l}\text { Innovation } \\
\text { effectiveness }\end{array}$ & $\begin{array}{l}\text { To improve the quality of innovation outputs, increase the quality and quantity of new ideas } \\
\text { and improve the chances of new products succeeding }\end{array}$ \\
\hline Teamwork & $\begin{array}{l}\text { To enhance teamwork in innovation, encouraging better communication (physical or } \\
\text { virtual), encourage formal and informal social interaction and motivate staff }\end{array}$ \\
\hline Customer input & $\begin{array}{c}\text { To enable customer input at any (or a specific) stage of the innovation process (from idea } \\
\text { through to evaluation concepts and product demonstration to support sales) }\end{array}$ \\
\hline Capabilities & Development of specific capabilities for enabling and renewal of dynamic capabilities \\
\hline
\end{tabular}

Table 1: Strategic intent of innovation environments 


\section{Process of creation}

\begin{tabular}{|c|c|}
\hline \multicolumn{2}{|r|}{ Process of creation } \\
\hline $\begin{array}{l}\text { Intended links with } \\
\text { the innovation } \\
\text { process }\end{array}$ & $\begin{array}{l}\text { The stage of the innovation process in which the environment is intended to be used, } \\
\text { including research (e.g. technology, markets and users), design (e.g. ideation, modelling, } \\
\text { evaluation), implementation (e.g. detailed engineering, launch) and exploitation (e.g. } \\
\text { selling, promoting, demonstrating). The degree to which the environment is explicitly or } \\
\text { implicitly coupled to the firm's innovation process - are outputs from the space fed into } \\
\text { the innovation process and is the space modified to reflect changes in the innovation } \\
\text { process? }\end{array}$ \\
\hline $\begin{array}{l}\text { Intended creative } \\
\text { activities }\end{array}$ & $\begin{array}{l}\text { The intended role of the space in supporting creative processes: search, synthesis, } \\
\text { creation, modelling and evaluation }\end{array}$ \\
\hline $\begin{array}{l}\text { Potential users \& } \\
\quad \text { facilitators }\end{array}$ & $\begin{array}{l}\text { The intended users of the space: from occasional multi-functional teams through to } \\
\text { dedicated environments for co-located project teams. The degree to which activities } \\
\text { within the space are intended to be facilitated by specialists in either content (e.g. } \\
\text { electronics) or processes (e.g. creativity) }\end{array}$ \\
\hline $\begin{array}{l}\text { Available resources } \\
\text { \& constraints }\end{array}$ & $\begin{array}{c}\text { The intended availability of physical (e.g. rooms), financial, human and technical } \\
\text { resources }\end{array}$ \\
\hline Intended events & $\begin{array}{l}\text { The type of 'events' intended in the space, from one off meetings through to ongoing } \\
\text { project work }\end{array}$ \\
\hline
\end{tabular}

\section{Table 2: Factors in the process of creation}

\begin{tabular}{|c|c|}
\hline \multicolumn{2}{|r|}{ Process of use } \\
\hline $\begin{array}{l}\text { Supporting } \\
\text { innovation }\end{array}$ & $\begin{array}{l}\text { The stage of the innovation process in which the environment is actually used, including } \\
\text { research (e.g. technology, markets and users), design (e.g. ideation, modelling, } \\
\text { evaluation), implementation (e.g. detailed engineering, launch) and exploitation (e.g. } \\
\text { selling, promoting, demonstrating). Actual links with the firm's innovation process. }\end{array}$ \\
\hline Supporting design & $\begin{array}{l}\text { The actual way in which the environments supports design activites and connects with } \\
\text { the design process. }\end{array}$ \\
\hline $\begin{array}{l}\text { Supporting } \\
\text { creativity }\end{array}$ & $\begin{array}{c}\text { The actual role of the space in supporting creative processes: search, synthesis, } \\
\text { creation, modelling and evaluation }\end{array}$ \\
\hline Enabling teamwork & The actual role of the space in enabling physical and virtual teamwork \\
\hline $\begin{array}{l}\text { Actual users \& } \\
\text { facilitators }\end{array}$ & $\begin{array}{l}\text { The actual users of the space: from occasional multi-functional teams through to } \\
\text { dedicated environments for co-located project teams. The degree to which activities } \\
\text { within the space are facilitated by specialists in either content (e.g. electronics) or } \\
\text { processes (e.g. creativity) }\end{array}$ \\
\hline Actual events & $\begin{array}{l}\text { The actual type of events held, from short one-off workshops, through to ongoing daily } \\
\text { activities }\end{array}$ \\
\hline
\end{tabular}

Table 3: Factors in the process of use 


\begin{tabular}{c|c}
\hline \begin{tabular}{c} 
Physical embodiment \\
\hline Seographic location
\end{tabular} & $\begin{array}{c}\text { The physical location of the environment and its relationship with the firm. This might } \\
\text { include standard office space, through to third-party external facilities. }\end{array}$ \\
\hline $\begin{array}{c}\text { The physical scale of the environment, from multi-room office spaces, through to singl- } \\
\text { room dedicated environments (e.g. idea room) }\end{array}$ \\
\hline $\begin{array}{c}\text { Flexibility } \\
\begin{array}{c}\text { Design values \& } \\
\text { imagery }\end{array}\end{array}$ & $\begin{array}{c}\text { The degree to which the space is designed around virtual teamwork and communication } \\
\text { The degree of flexibility embodied in the environment to enable alternative configurations } \\
\text { and uses. The degree of flexibility / reconfigurability of resources in the workspace. } \\
\text { Specific design values targeted at encouraging specific behaviours (e.g. futuristic, } \\
\text { playful, minimalist etc). The use of imagery to reinforce actions (e.g triangular room for } \\
\text { creative divergence) }\end{array}$ \\
\hline $\begin{array}{c}\text { IT Resources } \\
\text { Data \& information }\end{array}$ & $\begin{array}{c}\text { The role of IT to enable group work, activities and processes. IT resources may enable } \\
\text { both physical and virtual group work. }\end{array}$ \\
\hline $\begin{array}{c}\text { Modelling \& } \\
\text { visualisation } \\
\text { resources }\end{array}$ & $\begin{array}{c}\text { Availability of equipment, facilities and tools to support/enable modelling and visualisation } \\
\text { activities as a core component of creative and design processes. Visualisation tools } \\
\text { might range from simple flipchart, through to large scale IT enabled visualisation. } \\
\text { Modelling tools might range from rapid prototyping through to simple cardboard. }\end{array}$ \\
\hline Constraints & $\begin{array}{c}\text { Practical constraints on the design of the environment (e.g. building / room availability, } \\
\text { finances, skills etc) }\end{array}$ \\
\hline Evolution & $\begin{array}{c}\text { The evolution of the environment in response to emergent group needs and changes to } \\
\text { business strategies. The degree to which evolution is planned to meet future goals. }\end{array}$ \\
\hline
\end{tabular}

Table 4: Physical embodiment of intent 


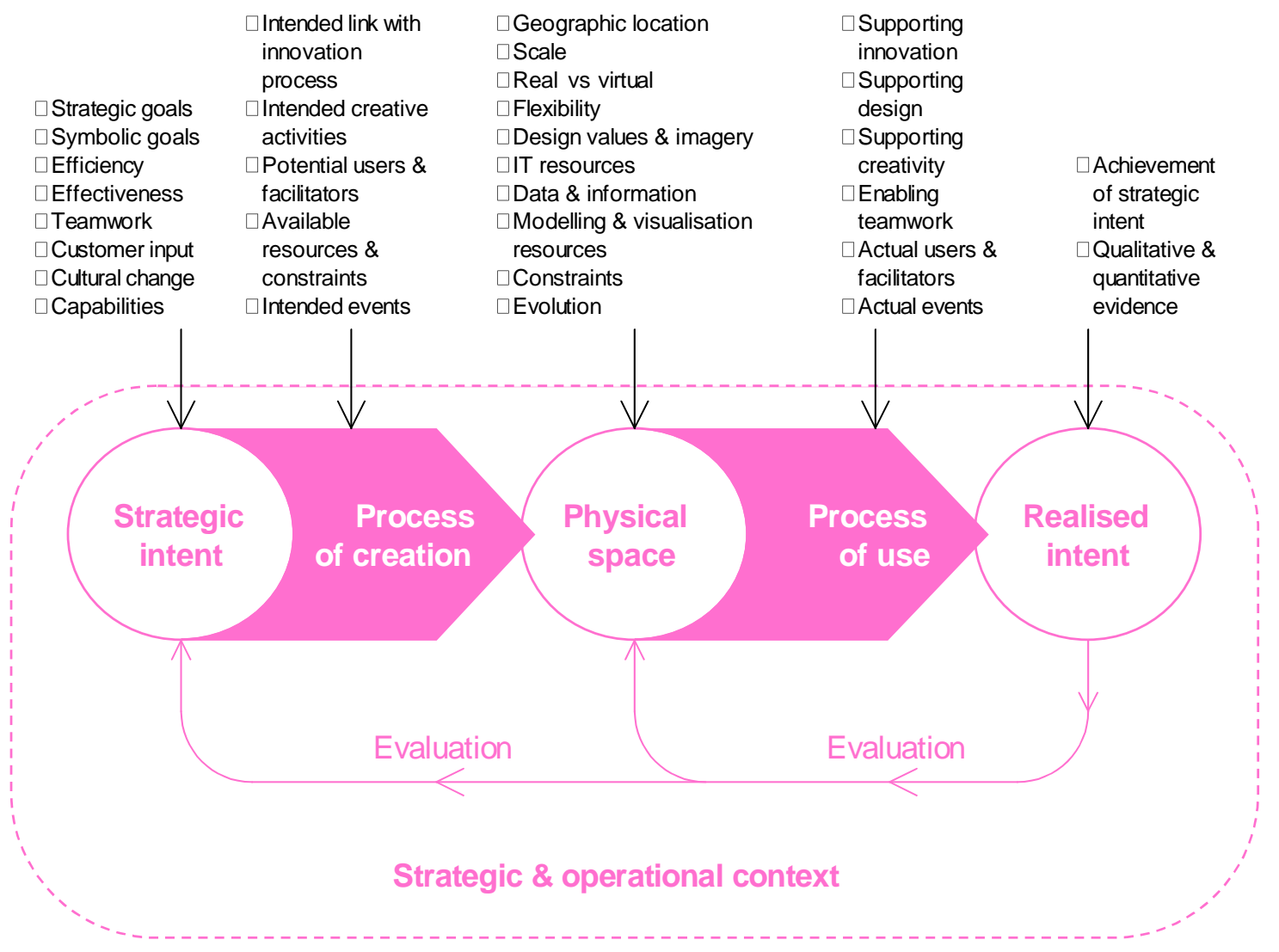

Figure 3: Conceptual framework 